\title{
The ceramic artifacts in archaeological black earth (terra preta) from Lower Amazon region, Brazil: chemistry and geochemical evolution.
}

\author{
Marcondes Lima da COSTA ${ }^{1 *}$, Dirse Clara KERN² ${ }^{2}$ Alice Helena Eleotério PINTO $^{1}$, Jorge Raimundo da \\ Trindade SOUZA ${ }^{3}$
}

\begin{abstract}
This paper carried out a chemical investigation of archaeological ceramic artifacts found in archaeological sites with Black Earth (ABE) in the Lower Amazon Region at Cachoeira-Porteira, State of Pará, Brazil. The ceramic artifacts, mostly of daily use, belong to Konduri culture (from 900 to 400 years $\mathrm{BP}$ ). They are constituted of $\mathrm{SiO}_{2}, \mathrm{Al}_{2} \mathrm{O}_{3}, \mathrm{Fe}_{2} \mathrm{O}_{3}, \mathrm{Na}_{2} \mathrm{O}$ and $\mathrm{P}_{2} \mathrm{O}_{5} ; \mathrm{SiO}_{2}$ and $\mathrm{Al}_{2} \mathrm{O}_{3}$ together add up to $80 \%$ and indicate influence of acid rocks, transformed into clay minerals basically kaolinite. The relative high contents of $\mathrm{P}_{2} \mathrm{O}_{5}(2.37 \%$ in average) come out as (Al,Fe)-phosphate, an uncommon fact in primitive red ceramics, but found in some roman and egyptian archaeological sites. The contents of the trace elements are similar or below the Earth's crust average. This chemical composition (except $\mathrm{P}_{2} \mathrm{O}_{5}$ ) detaches saprolite material derived acid igneous rocks or sedimentary ones as the main raw material of the ceramics. The contents of $\mathrm{K}, \mathrm{Na}$ and $\mathrm{Ca}$ represent the feldspars and rock fragments possibly introduced into saprolitic groundmass, indicated by mineralogical studies. The presence of cauixi and cariapé as well as quartz sand was confirmed by optical microscope, SEM analyses and by the high silica contents of ceramic fragments. Phosphorus was possibly incorporated into groundmass during cooking of foods, and ABE soil profile formation developed on yellow Latosols. The raw materials and its tempers (cauixi, or cariapé, feldspar, crushed rocks, old ceramic artifacts and quartz fragments) are found close to the sites and therefore and certainly came from them.
\end{abstract}

\section{KEY WORDS}

Terra preta, Black earth, Lower Amazon, Soil, Chemistry, Phosphorus, Geochemical Evolution

\section{Artefatos cerâmicos em sítios arqueológicos com terra preta na região do baixo Amazonas, Brasil: composição química e evolução geoquímica.}

\begin{abstract}
RESUMO
Neste trabalbo realizou-se a caracterização química de fragmentos de artefatos cerâmicos encontrados em sítios arqueológicos com terra preta no Baixo Amazonas (Cachoeira-Porteira, Pará, Brasil), representativos da cultura Konduri (de 900 a 400 anos $\mathrm{AP}$ ). Esses fragmentos são constituídos de $\mathrm{SiO}_{2}, \mathrm{Al}_{2} \mathrm{O}_{3}, \mathrm{Fe}_{2} \mathrm{O}_{3}, \mathrm{Na}_{2} \mathrm{O}$ e $\mathrm{P}_{2} \mathrm{O}_{7}$, sendo que $\mathrm{SiO}_{2}$ e $\mathrm{Al}_{2} \mathrm{O}_{3}$ juntos, perfazem mais de $80 \%$ em peso. Os teores de $P_{2} \mathrm{O}_{5}$ são relativamente elevados (2,37\% em média) sob a forma de (Al,Fe)-fosfatos, incomuns em cerâmicas vermelhas primitivas, mas encontrados em algumas cerâmicas arqueológicas egípcias e romanas. As concentrações dos elementos traços são comparáveis ou mesmo inferiores ao nível crustal, embora a composição total seja próxima a mesma. A composição química (exceto $\mathrm{P}_{2} \mathrm{O}_{5}$ ) em conjunto com os dados mineralógicos e texturais indicam material saprolítico derivado de rochas ígneas félsicas ou rochas sedimentares como matéria-prima das cerâmicas. Os teores de K, Ca e Na mostram que os feldspatos e fragmentos de rochas foram adicionados ao material argiloso, como sugerido pela mineralogia. Os altos teores de sílica respondem pela presença de cauixi, cariapé e/ou areias quartzosas. Fósforo deve ter sido incorporadoà matriz argilosa da cerâmica, quando do cozimento de alimentos nos vasos cerâmicos, $e$ ainda, em parte, durante a formação do perfil de solo tipo ABE sobre Latossolos Amarelos. A matéria prima e os temperos (cauixi, cariapé, rochas trituradas e fragmentos de vasos cerâmicos descartados) encontram-se disponíveis próximos aos sítios até a atualidade, e portanto foram a área fonte dos mesmos para a confecção dos artefatos cerâmicos..
\end{abstract}

\section{PALAVRAS-CHAVE}

Terra preta, Baixo Amazonas, Solos, Composição química, Fósforo, Evolução geoquímica.

${ }^{1}$ Geosciences Center/UFPa, 66075-110 Belém-PA, Brazil, P.O . Box 1611 Fax: (091) 211 1609/211 1428, Phone: (091) 211 1428/249 5028, E-mail: mlc@ufpa.br

${ }^{2}$ Museu Paraense Emílio Goeldi/MPEG, Belém-PA, Brazil.

${ }^{3}$ Chemistry Department/UFPa, 66075-110 Belém-PA, Brazil 


\section{ACTA \\ AMAZONICA}

THE CERAMIC ARTIFACTS IN ARCHAEOLOGICAL BLACK EARTH (TERRA PRETA) FROM LOWER AMAZON REGION, BRAZIL: CHEMISTRY AND GEOCHEMICAL EVOLUTION

\section{INTRODUCTION}

After Costa et al., (2004) the black earth soils, called by natives Indian black earth (Terra Preta de Índio in Portuguese) or by archaeologists as archaeological black each $(A B E)$ are very commonly found in the landscape of the Amazon region and described by naturalists, archaeologists and pedologists (Smith, 1879; Ranzani et al., 1962; Sombroek, 1966; Balee, 1986; Kern \& Kampf, 1989, 1990). Pedological studies and morphological description and classification of their ceramics artifacts as important tools for understanding the peopling of the Amazon region were carried out (Ranzani et al., 1962; Falesi, 1974; Simoes, 1982; Eden et al., 1984; Kern (1988), Kern \& Kampf (1989 E 1990), Kern et al., (1997). Multi-element geochemistry was conducted at Caxiuana bay by Kern (1996), Kern \& Costa, (1997) and Costa \& Kern (1999). Although very abundant in the ABE sites, the fragments of ceramics artifacts have not yet been investigated. The first attempt was realized by Costa et al., (2004), who studied the mineralogy of the fragments of ceramic artifacts from CachoeiraPorteira. The present work carried out a chemical characterization of these materials, which represent the Konduri style culture (Nimuendaju, 1948), in order to complete the previous investigation of Costa et al., (2004) and to contribute to understand the pre-historic peopling of the Amazon region. The results obtained until now show that the black earth may be a pedological, chemical and mineralogical modification of preexisting soils by pre-historic human (Indian) activities and settling in the later past time. Mineralogical and geochemical techniques have been successfully applied in the last decades to study archaeological artifacts in order to improve the interpretation of the archaeological data (Noll, 1978; Zaun, 1982; Letsch \& Noll, 1983; Momsen, 1986, Freestone \& Middleton, 1987; Redmont, 1996; Strazicich, 1999; Costa et al. 1991; Costa \& Kern, 1996 ).

Along the Trombetas river and its tributaries, there are several archaeological sites (Ranzani et al., 1962; Kern, 1988). Close to the village Cachoeira-Porteira (Oriximiná Municipality, state Pará), the investigated area on the Trombetas river, occu sever site of ABE (Fig.1).

The actual climate is rainy equatorial, with tropical forest. The drainage system is dense, the valleys are overflowed, and normally have a rocky bottom, and under these conditions water falls and/or rapids are present.

The soils are composed mainly by yellow to red Latosols, yellowish brown Podzols and Structured Red Earth (Terra Roxa Estruturada). The ABE are classified as anthropogenic soils (Ranzani et al., 1962, Kern, 1988; Kern, 1996), developed primordially over the llow Latosols and Petroplinthosol (Kern, 1988: Kern \& Kaempf, 1989).

Paleozoic to Mesozoic sedimentary rocks (sandstones and claystones) of Lower Amazon basin covering the proterozoic volcanic acid rocks of Iricoumé Formation and the Mapuera Granite constitute the main geological units of the region and are crosscut by basic dikes. Laterite profiles caped by Latosols are also common, as well as holocene clays, sands and pebbles on the riverbanks and lakes (Costa et al., 2004).

\section{MATERIALS AND METHODS}

\section{Sampling}

The fragments of ceramic artifacts of ABEs with distinct tempers investigated here were collected by MPEG (Museu Paraense Emilio Goeldi) in 1988, with the participation of coauthor Dirse Clara Kern in antecipation of the lake projected for hydroelectric power of Cachoeira-Porteira. For the present work 51 samples of ceramic fragments covering all the types of tempers were taken from the sites 1 (PA-OR-73) and 2 (PA-TR2) (Fig.1). After Meggers \& Evans (1970) tempers are exotic material intentionally put in the ceramics during their confection. The identified tempers are mainly ceramic fragments with cariapé; ceramics with cauxi; ceramics with sand; ceramics with sand plus feldspar; and ceramics with older crushed ceramics. The sampling was performed along standard trenches along the soil horizons $\mathrm{A}_{\mathrm{p}}, \mathrm{A}_{1}, \mathrm{~A}_{2}$ and $\mathrm{A}_{3}$, the horizons that carry ceramic fragments. The mineralogical study of these materials was carried out by Costa et al (2004).

\section{Chemical Analyses}

Whole chemical analyses of 22 samples of ceramic fragments with distinct tempers were performed by XRF spectrometry, atomic absorption spectrometry and wet chemical methods in the Centro de Geociências from Universidade Federal do Pará-UFPa. XRF, OES (optical emission spectrograph), and ICP-AES were also performed in four selected samples for major and trace elements at Lakefield-Geosol (Belo Horizonte, Brazil). These four samples were also investigated by Scanning Electron Microscope with Energy Dispersive System at the laboratory facilities of the Companbia Brasileira de Metalurgia e Mineração-CBMM, in São Paulo, in order to get images and chemical analyses.

\section{RESULTS AND DISCUSSION}

\section{Chemical Composition}

To help understanding the chemical treatment and discussion of chemical analyses it should be very important to summarize the physical composition of the ceramic fragments after each temper described by Costa et al. (2004). Quartz and burned clay-derived mineral (originally interpreted to be kaolinite) are the more abundant minerals. Feldspars (albite and microcline) are frequent in ceramic 


\section{ACTA AMAZONICA}

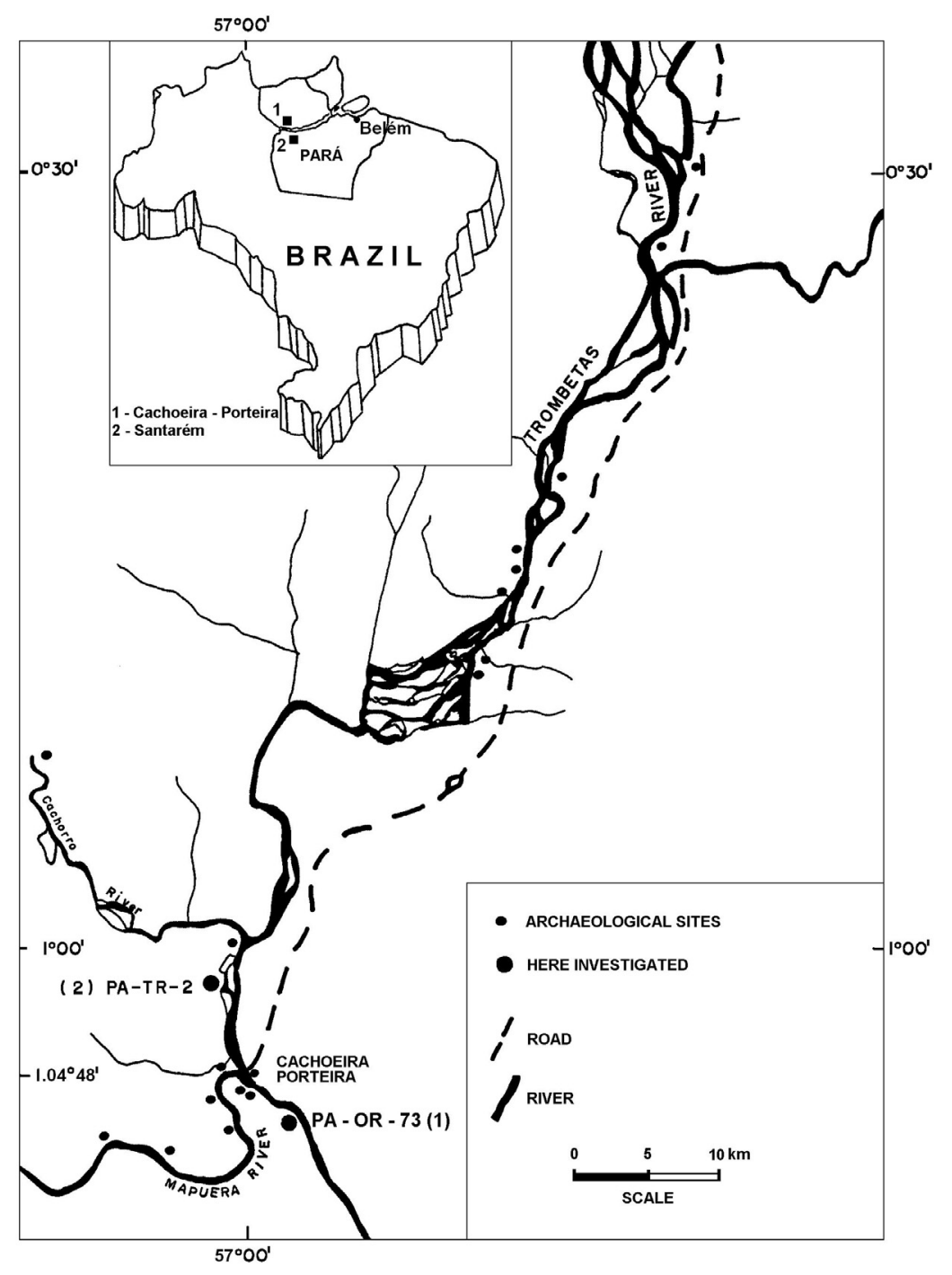

Figure 1 - Location map of two sites of archaeological black earth (ABE) investigated at Cachoeira-Porteira, Lower Amazon region (after COSTA et al., 2004).

fragments with sand and feldspar tempers. Illite, hematite, maghemite, goethite, and anatase are found in low quantities for all ceramic fragment tempers. Although in less quantities (3 to 11 wt.\%) amorphous and microcrystalline aluminum phosphates are found all over the ceramic fragments. Cauxi and cariapé are the organic tempers found in several ceramic fragments, and after their presence are the ceramic fragments classified into cauixi or cariapé temper.

The results of the chemical analyses (Table 1) show small variation among the average of the different tempers. This is clearly demonstrated by diagrams $\mathrm{SiO}_{2}-\mathrm{Al}_{2} \mathrm{O}_{3}-\mathrm{K}_{2} \mathrm{O}$ (Fig. 2) and $\mathrm{Fe}_{2} \mathrm{O}_{3}-\mathrm{P}_{2} \mathrm{O}_{5}-\mathrm{TiO}_{2}$ (Fig. 3), where most samples fall close together, the ceramic fragments with sand+feldspar temper being less similar.

$\mathrm{SiO}_{2}$ values vary from 63.5 to $70.8 \mathrm{wt}$ \% (the average of each ceramic temper), and those from $\mathrm{Al}_{2} \mathrm{O}_{3}$ from 14.7 to $17.4 \mathrm{wt} \%$, and together comprise more than $80 \mathrm{wt} . \%$ of whole ceramic chemical composition. $\mathrm{Fe}_{2} \mathrm{O}_{3}$ is the third most abundant element and reaches $5.79 \mathrm{Wt}$. \% on average. The alkali elements (as $\mathrm{K}_{2} \mathrm{O}, \mathrm{Na}_{2} \mathrm{O}, \mathrm{CaO}$ and $\mathrm{MgO}$ ) constitute together less than 3 wt. \%. On the other side come out the relative high contents of $\mathrm{P}_{2} \mathrm{O}_{5}, 2.37$ wt. \% in average. The $\mathrm{H}_{2} \mathrm{O}+$ values reach 7.54 wt. \% on average, which is still high for burned ceramic material (mainly clay material). The $\mathrm{Al}_{2} \mathrm{O}_{3}$ and $\mathrm{H}_{2} \mathrm{O}+$ contents explain the great abundance of clay-derived minerals.. The relative high contents of $\mathrm{H}_{2} \mathrm{O}+$ confirm the abundance of partial dehydroxylation of clay-material derived from kaolinite as main mineral of the ceramics and the neoformation of kaolinite (Costa et al., 2004). It means that the fragments reabsorved water along its discarded and incorporation into ABE-soil formation. The extremely high $\mathrm{SiO}_{2}$ contents correspond, besides clay-derived material and the abundance of quartz, as sand grains and rock fragments, to the presence of cauixi (Tubella reticulata and Parnula betesil), and cariapé (Bignomiacea, Moquilea, Licania utilis, and Turiuva; Hilbert, 1955). Cauixi and cariapé are the $\mathrm{SiO}_{2}$-bearing organic materials (Costa et al., 1991, 2004). The iron contents represent hematite and goethite, and some maghemite, minerals also identified in the studied ceramic fragments. $\mathrm{K}_{2} \mathrm{O}, \mathrm{Na}_{2} \mathrm{O}$ and $\mathrm{CaO}$ built the feldspars (microcline and albite) and together with $\mathrm{MgO}$ indicate the presence of illite in the raw material. The predominance of $\mathrm{SiO}_{2}, \mathrm{Al}_{2} \mathrm{O}_{3}$ and $\mathrm{H}_{2} \mathrm{O}+$ plus $\mathrm{Fe}_{2} \mathrm{O}_{3}$ (together they make up more than $93 \mathrm{Wt}$. \% of whole sample) confirm clay-derived minerals, quartz and some iron oxyhydroxides as the main minerals of ceramic fragments. The chemical and mineralogical data, as well as textural aspects, leave one to conclude that the main raw material for ceramic elaboration comes from fine-grained clayquartz rich material (for example saprolites, claystones, shales, and so on). The $\mathrm{P}_{2} \mathrm{O}_{5}$ contents however are relatively high for clay material normally used for ceramic purpose. They compose basically the amorphous to criptocrystalline (Al,Fe)-phosphate. The $\mathrm{H}_{2} \mathrm{O}+$ contents are still high (5.6 to $8.9 \mathrm{Wt} \%$ ) showing the rehydration of the ceramic vessel after theeir discharging and the formation of the soil with black earth, the formation of $\mathrm{ABE}$, and as consequence the neoformation of kaolinite and goethite after Costa et al. (2004). 


\section{ACTA \\ AMAZONICA \\ THE CERAMIC ARTIFACTS IN ARCHAEOLOGICAL BLACK EARTH (TERRA PRETA) FROM \\ LOWER AMAZON REGION, BRAZIL: CHEMISTRY AND GEOCHEMICAL EVOLUTION}

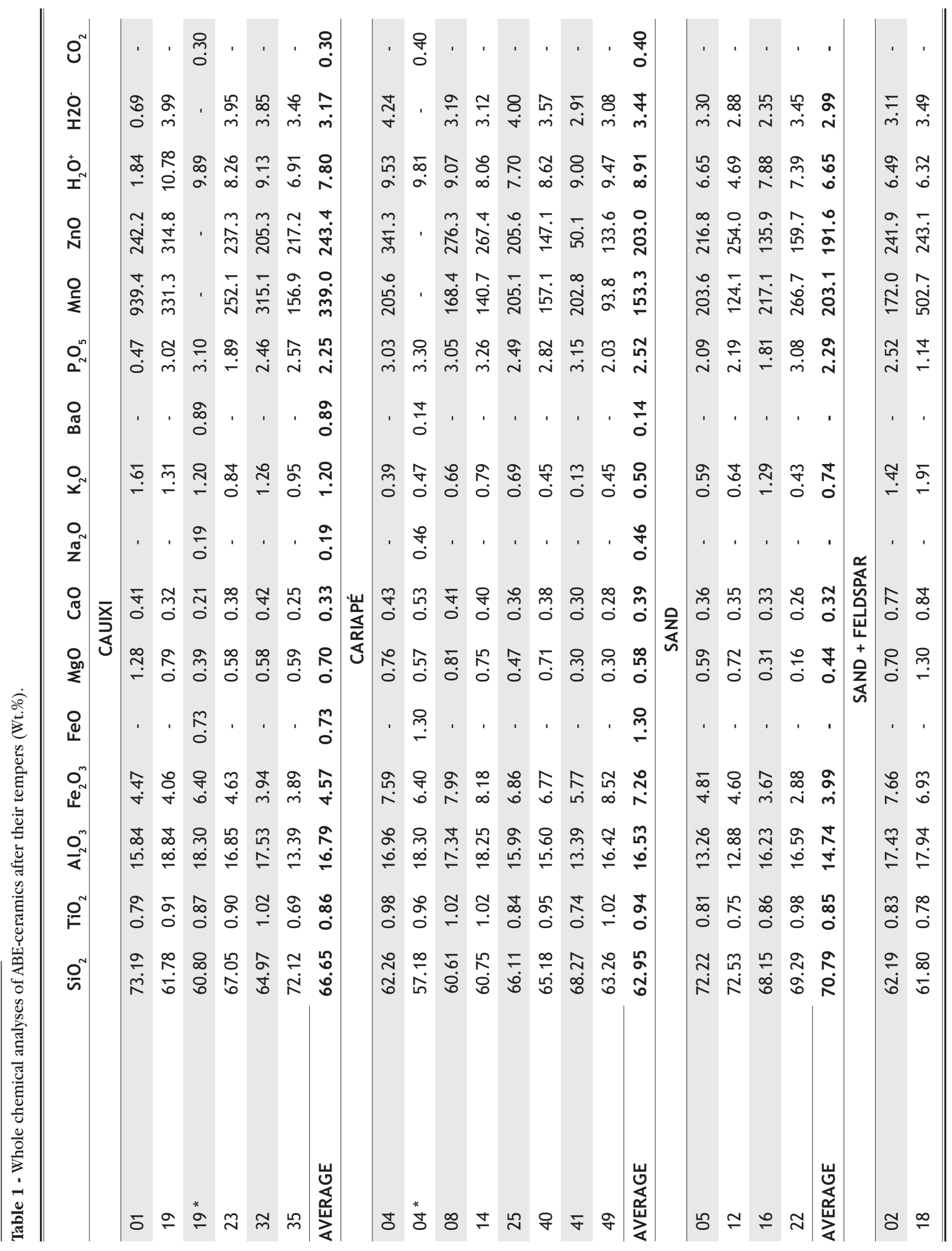




\section{ACTA \\ AMAZONICA}

THE CERAMIC ARTIFACTS IN ARCHAEOLOGICAL BLACK EARTH (TERRA PRETA) FROM LOWER AMAZON REGION, BRAZIL: CHEMISTRY AND GEOCHEMICAL EVOLUTION

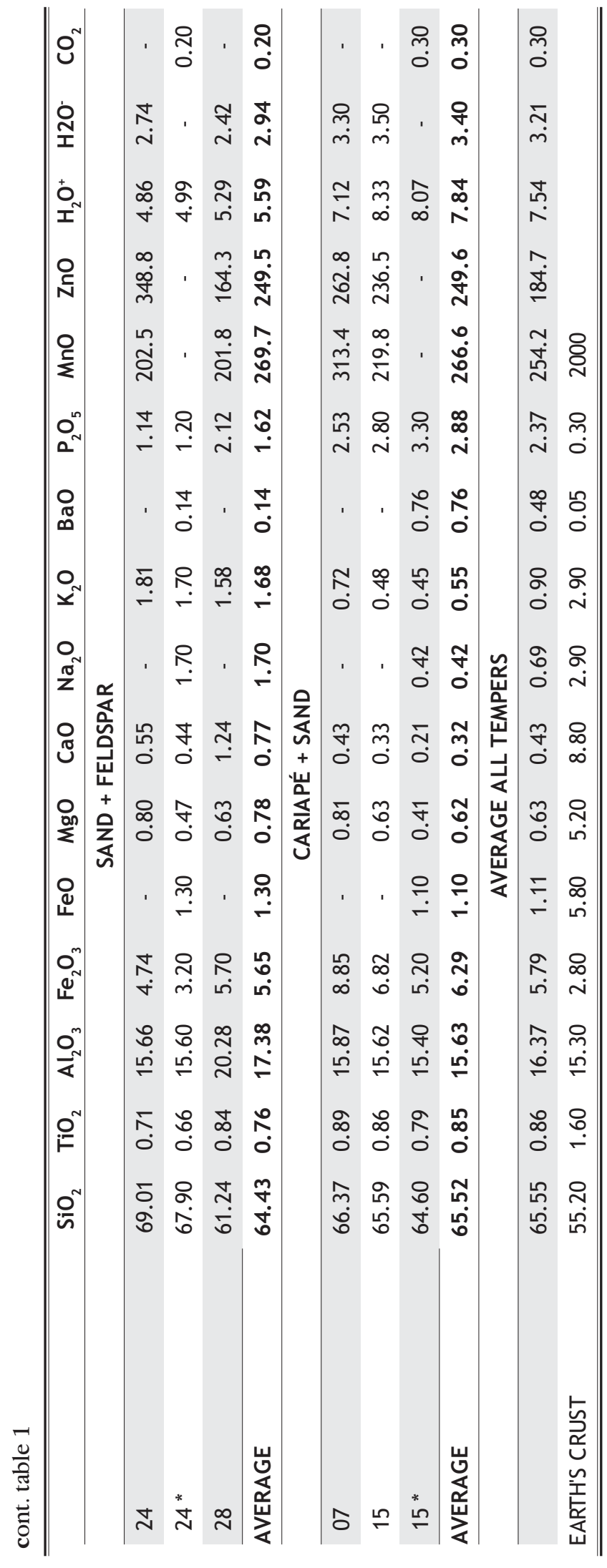

\section{Identification of the main raw material after chemical composition}

The diagram $\mathrm{SiO}_{2}-\mathrm{Al}_{2} \mathrm{O}_{3}-10\left(\mathrm{~K}_{2} \mathrm{O}\right)$ (Fig.2) show that ceramics have a single field composition, nearest to the field of granitic saprolite and then to shale and the Earth's crust average. On the other hand the average of each ceramic fragment temper studied here are aligned in a single field parallel to the $\mathrm{P}_{2} \mathrm{O}_{5}-\mathrm{Fe}_{2} \mathrm{O}_{3}$-edge of the diagram $\mathrm{Fe}_{2} \mathrm{O}_{3}-\mathrm{TiO}_{2}$ $\mathrm{P}_{2} \mathrm{O}_{5}$ (Fig. 3), far from the Earth's crust composition, saprolite derived from granite and shale. This deviation is caused by the anomalous contents of $\mathrm{P}_{2} \mathrm{O}_{5}$ and indicates that $\mathrm{P}_{2} \mathrm{O}_{5}$ was not a part of the original material but was probably incorporated after the elaboration of the ceramic vessels, certainly during the their daily use and/or afterward the discard of them.

The contents of trace elements are similarly distributed inside of different ceramic tempers in the same way as the major elements. It means that the ceramic vessels independent of ceramic tempers were made of quite similar raw materials. If these elements are compared to their average in the Earth's Crust they show the following pattern: a) elements with contents clearly above the Earth's crust level: $\mathrm{Zn}, \mathrm{Ba}, \mathrm{Pb}, \mathrm{Zr}$, Y, Mo, Sc and Sn e; b) contents similarly to the Earth's crust average : $\mathrm{Cu}, \mathrm{B}, \mathrm{La}, \mathrm{Ce}, \mathrm{Nd}$ and $\mathrm{Eu} ; \mathrm{c}$ ) contents below the Earth's crust average : $\mathrm{Cl}, \mathrm{Co}, \mathrm{Ga}, \mathrm{V}, \mathrm{Y}$, $\mathrm{Mn}, \mathrm{Sm}, \mathrm{Gd}, \mathrm{Dy}, \mathrm{Ho}, \mathrm{Er}, \mathrm{Yb}$ and $\mathrm{Lu}$ ).

The organic foreign materials, cauixi and cariapé, display a very low content of trace elements, specially cariapé (Table 2 ). Only Ba reaches $152 \mathrm{ppm}$ in cariapé, although in the ceramic it can reach up to 0.89 wt. \% of $\mathrm{BaO}$. This $\mathrm{BaO}$ values is too high even for feldspar-bearing rocks. Locally $\mathrm{Ba}$, sometimes $\mathrm{Mn}$, are strong concentrated in the matrix as showed previously by SEM/EDS analyses. They form their own mineral, interpreted to be Mn-oxyhydroxides(Costa et al., 2004). Barium, phosphorus and even $\mathrm{Pb}$ seem to be the anomalous elements found in the ceramic fragments of Cachoeira-Porteira. The anomalous values of $\mathrm{Ba}$ were frequently found in the ceramic fragments with cauixi and cariapé +sand temper.

In general the contents of trace elements found in the ceramic fragments of Cachoeira-Porteira, can be well correlated to saprolites derived either from granites/rhyolites or to granodiorites/dacites. They can be slightly correlated to the Earth's Crust average as well. The higher contents of $\mathrm{Zr}$, Sc and Sn might have been promoted by weathering processes forming the saprolite, confirmed by the decreasing of $\mathrm{Cl}, \mathrm{Co}$, $\mathrm{Cu}, \mathrm{V}, \mathrm{Mn}$ and heavy rare earth elements (Sm, Gd, Dy, Ho, Er, $\mathrm{Yb}$ and $\mathrm{Lu}$ ) as demonstrated before. The contents of the rare earth elements (REE) fall in the domain of the Earth's crust abundance and granitic rocks and its weathered products.

The distribution curves of REE normalized to chondrites (Fig. 4) are quite similar to each other and display a negative Eu-anomaly and depletion toward HREE. This pattern falls close to granite-derived saprolite and is only partially comparable with the Earth's crust and granite average. Cauxi and cariapé present a distinct pattern with 


\section{ACTA AMAZONICA}

THE CERAMIC ARTIFACTS IN ARCHAEOLOGICAL BLACK EARTH (TERRA PRETA) FROM LOWER AMAZON REGION, BRAZIL: CHEMISTRY AND GEOCHEMICAL EVOLUTION very low concentration of REE and therefore do not contribute to relative high concentration of REE found in the ceramic fragments.

Unlikely the saprolite formation can not promote the strong increasing of the contents of elements like $\mathrm{Ba}, \mathrm{Zn}$ and $\mathrm{Pb}$ (expecting a weathering of acid igneous rocks or common clay sedimentary rocks). These elements similarly to phosphorus, La, Ce, Nd and $\mathrm{Mn}$ as earlier described, they (mainly $\mathrm{Ba}$ and $\mathrm{Pb}$ ) were probably introduced after ceramic elaboration.

The major and trace elements indicate that the main raw materials used for the elaboration of the ceramic artifacts have a composition close do saprolite derived from acid rocks (finegrained granite/rhyolite) or shales and claystones. However, elements like $\mathrm{P}, \mathrm{Ba}$ and $\mathrm{Pb}(\mathrm{Zn})$ and their minerals present as foreign components of the raw materials. They may have been possibly incorporated only after the elaboration of the ceramic vessels, probably during cooking and other daily uses.

\section{THE ORIGIN OF CERAMIC RAW MATERIAL AND THEIR TRANSFORMATION DURING USE AND DISCARD (AS ABE COMPONENT)}
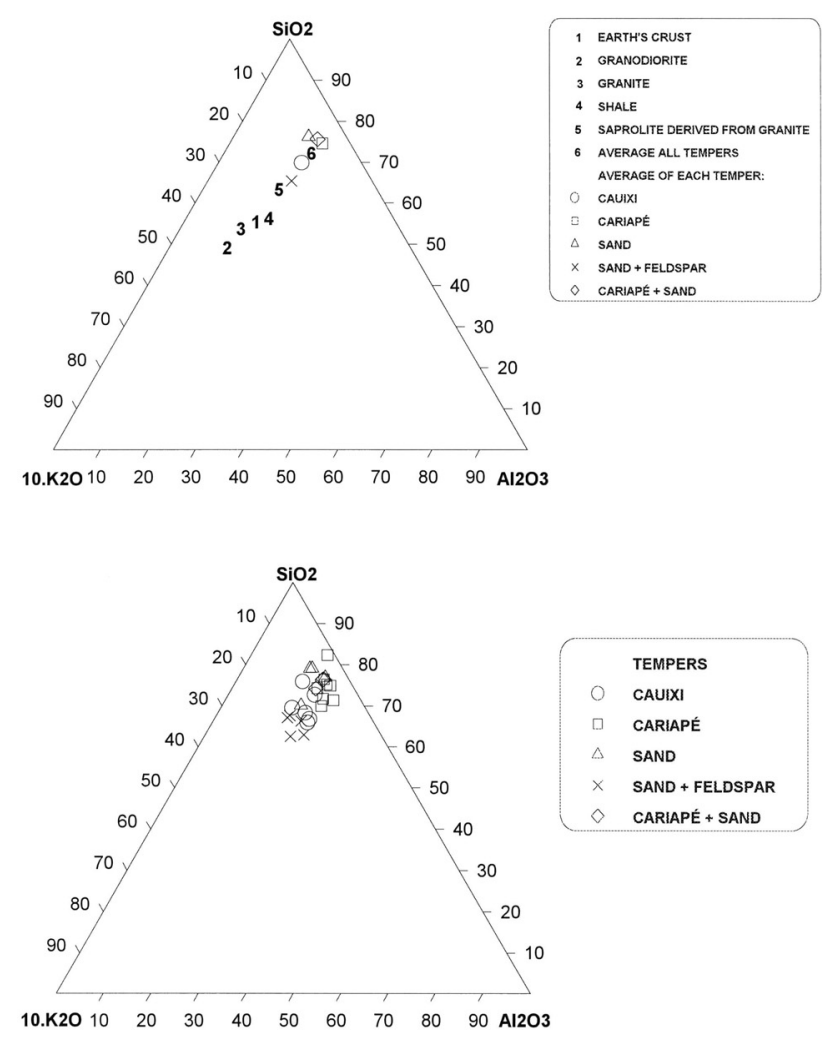

Figure 2 - Chemical composition of the ceramics on the diagram $\mathrm{SiO}_{2}-10 \mathrm{~K}_{2} \mathrm{O}-\mathrm{Al}_{2} \mathrm{O}_{3}$ compared to the composition of Earth's crust abundance, granite, granodiorite, shale and granitic saprolite

\section{The raw material of the ABE-ceramics}

Petrographical and chemical studies have been used by Redmount (1996) and Strazicich (1998) to identify the raw material and the source of ceramics from Egypt and Mexico, respectively. The chemical composition data obtained here and the textural and the mineralogical presented by Costa et al., (2004) allow us to propose the following materials as raw materials for the ceramics of Cachoeira-Porteira:

1) Clay materials (mainly kaolinite) from the saprolite horizons or mottled zone of weathered fine-grained acid rocks, for example rhyolites and/or fine-grained granites or even clayey sedimentary rocks (shale). The high contents of $\mathrm{Al}_{2} \mathrm{O}_{3}$ and $\mathrm{SiO}_{2}$ are compatible to kaolinite-rich saprolite or mottled zone derived from that kind of rocks;

2) Slightly coarse crushed igneous rocks, e.g. granites, granodiorites, rhyolites and quartz of veins; they explain the presence of unweathered feldspars and roundless quartz grains (Costa et al., , 2004) and the relatively high content of $\mathrm{K}, \mathrm{Na}$ and $\mathrm{Ca}$ for the inferred saprolite. The addition of quartz grains, cauixi and cariapé has only promoted a slight unbalancing in $\mathrm{SiO}_{2}$ relatively to $\mathrm{Al}_{2} \mathrm{O}_{3}$ turned the composition a little far from Earth's Crust level (Fig. 2). In contrast, the feldspar grains

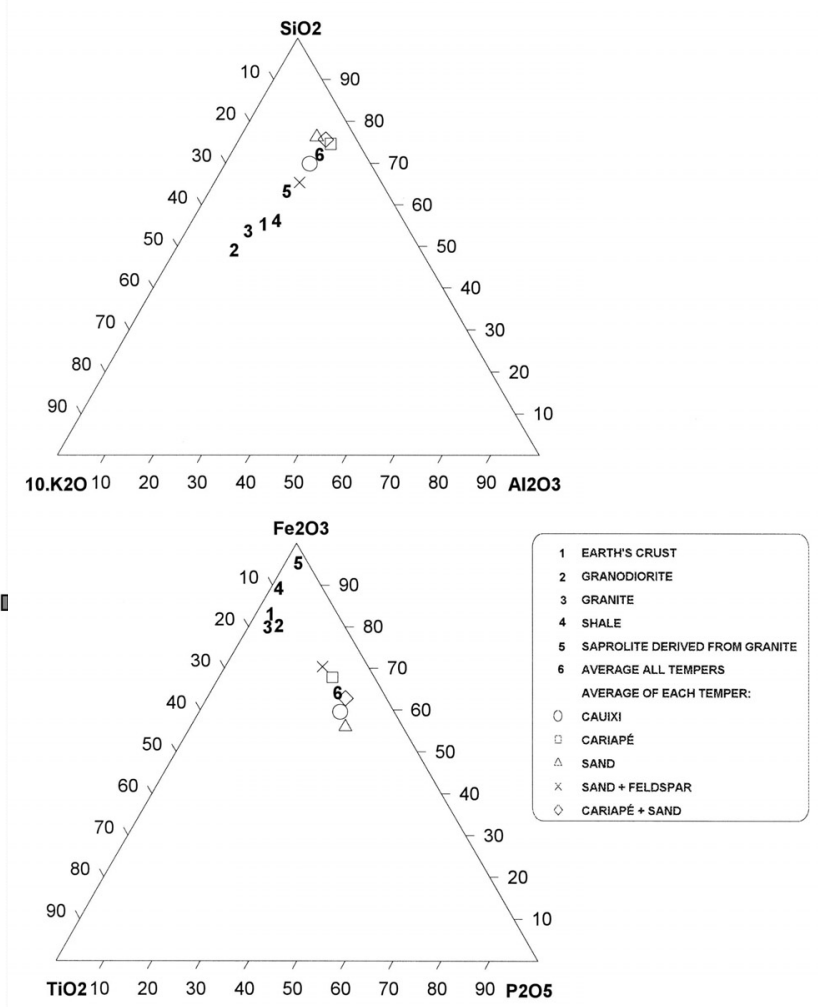

Figure 3 - Chemical composition of the ceramics on the diagram $\mathrm{Fe}_{2} \mathrm{O}_{3}-\mathrm{TiO}_{2}-\mathrm{P}_{2} \mathrm{O}_{5}$. 


\section{ACTA AMAZONICA}

Table 2 - Trace element contents (in ppm) of ABE-ceramics after their tempers, and of cauixi and cariapé.

\begin{tabular}{|c|c|c|c|c|c|c|c|c|c|c|c|c|c|c|c|}
\hline SAMPLES & $\mathrm{Cl}$ & Co & $\mathrm{Cu}$ & $\mathrm{Be}$ & B & $\mathrm{Zr}$ & $\mathrm{Ga}$ & Mo & v & Sc & $Y$ & Sn & $\mathrm{Pb}$ & $\mathrm{Zn}$ & $\mathrm{Sr}$ \\
\hline \multicolumn{16}{|l|}{ CERAMICS } \\
\hline CCP - 04 & 56 & 9 & 72 & $<2$ & $<10$ & 380 & $<5$ & 152 & 17 & 50 & $<5$ & 45 & 182 & 130 & \\
\hline CCP - 15 & 4 & 8 & 46 & $<2$ & $<10$ & 375 & $<5$ & 116 & 17 & 48 & $<5$ & 45 & 132 & 86 & \\
\hline CCP - 19 & 48 & 8 & 40 & $<2$ & $<10$ & 375 & $<5$ & 152 & 16 & 68 & $<5$ & 60 & 128 & 42 & \\
\hline CCP - 24 & 29 & 10 & 36 & $<2$ & $<10$ & 580 & $<5$ & 180 & 13 & 42 & $<5$ & 40 & 132 & 400 & \\
\hline AVERAGE & 34 & 9 & 49 & $<2$ & $<10$ & 428 & $<5$ & 150 & 16 & 52 & $<5$ & 48 & 144 & 165 & \\
\hline CAUIXI & & & 21 & - & 19 & 27 & $<5$ & 5 & 120 & $<5$ & 12 & - & 22 & $<200$ & - \\
\hline CARIAPÉ & & & 10 & - & 19 & $<10$ & $<5$ & $<5$ & 63 & $<5$ & $<10$ & - & $<10$ & $<200$ & - \\
\hline $\begin{array}{l}\text { EARTH'S } \\
\text { CRUST * }\end{array}$ & 130 & 22 & 50 & 3 & 10 & 165 & 18 & 1.5 & 110 & 20 & 35 & 2.5 & 12.5 & 70 & 375 \\
\hline SAMPLES & $\mathrm{Ba}$ & $\mathrm{Cr}$ & $M n$ & $\mathrm{Ni}$ & La & $\mathrm{Ce}$ & Nd & $\mathrm{Sm}$ & $\mathrm{Eu}$ & Gd & Dy & Ho & $\mathrm{Er}$ & Yb & Lu \\
\hline \multicolumn{16}{|l|}{ CERAMICS } \\
\hline CCP - 04 & & & & & 45.40 & 95.52 & 37.07 & 5.415 & 1.070 & 3.736 & 2.867 & 0.575 & 1.563 & 1.613 & 0.25 \\
\hline $\mathrm{CCP}-15$ & & & & & 39.52 & 83.26 & 29.96 & 5.055 & 0.924 & 3.583 & 3.191 & 0.655 & 1.842 & 1.920 & 0.25 \\
\hline CCP - 19 & & & & & 32.13 & 69.20 & 26.96 & 4.814 & 0.859 & 3.338 & 3.035 & 0.624 & 1.774 & 1.868 & 0.24 \\
\hline CCP - 24 & & & & & 23.82 & 51.72 & 22.54 & 3.947 & 0.097 & 2.729 & 2.334 & 0.488 & 1.426 & 1.411 & 0.20 \\
\hline AVERAGE & & & & & 35.22 & 74.84 & 29.13 & 4.810 & 0.940 & 3.350 & 2.857 & 0.585 & 1.651 & 1.710 & 0.24 \\
\hline CAUIXI & 44 & 18 & 58 & 19 & 5.945 & 11.20 & 3.77 & 0.380 & 0.108 & 0.325 & 0.292 & 0.050 & 0.130 & 0.172 & 0.03 \\
\hline CARIAPÉ & 152 & 22 & 25 & 17 & 9.854 & 18.55 & 3.28 & 0.600 & 0.067 & 0.310 & 0.235 & 0.042 & 0.110 & 0.128 & 0.02 \\
\hline $\begin{array}{l}\text { EARTH'S } \\
\text { CRUST * }\end{array}$ & 500 & 100 & 1,000 & 75 & 35 & 70 & 30 & 7 & 1.2 & 7 & 6 & 1.5 & 3.5 & 3.5 & 0.6 \\
\hline
\end{tabular}

obviously kept some $\mathrm{Na}_{2} \mathrm{O}, \mathrm{CaO}$, and $\mathrm{K}_{2} \mathrm{O}$ inside the clayey matrix, which can be observed in the chemical analyses of these ceramics (Table 1);

3) Cauixi and/or cariapé. They cannot be found naturally in saprolite or mottled zone. Cauixi can be observed in some young lake sediments and water column e.g. Caxiuanã bay in Eastern Amazon; cauixi are found as cm-long aggregates fixed in the trees on the margin of rivers and lakes with clear or black water, as well as dsitributed on the surface of bottom sediments of lakes and some black water rivers. Cariapé is a tree skin found in the neighboring forest. Both materials rich on $\mathrm{SiO}_{2}$ are common in the Amazon region and in the area studied here.

4) Older discarded ceramics. They possibly represent discarded ceramic vessels, that were intentionally fine crushed for reuse. The fine fragments obtained can be well characterized under optical microscope;

The texture of ceramics shows that the clay-derived matrix was the basic raw material into which crushed rocks and/or crushed minerals (feldspars and quartz), quartz sand, cauixi and/or cariapé and/or older ceramics were intentionally added. After the archaeologists the last four main components (crushed rocks, and minerals; quartz sand; cauixi und cariapé; and old ceramics) intentionally added are denominated tempers (Meggers \& Evans, 1970) and used to classify the archaeological ceramic fragments.

On the other hand there is no evidence of phosphorusand barium-lead-bearing raw material .

\section{The Source Area of Raw Material}

Weathered and unweathered rhyolites, granitic and granodioritic rocks occur quite near to the sites 1 and 2 (COSTA et al., 2004). Cauixi is found to the present day in many lakes and rivers near archaeological sites and in many places of the Amazon region. Cariapé can be found in the surrounding rain forest (Fig. 5) as well. The region is also rich in archaeological sites with $\mathrm{ABE}$ and potteries, that can be recycled. 


\section{Origin of Phosphorus and Phosphates and Other Elements like Mn and Ba.}

Phosphorus is one of the few chemical elements, which are completely anomalous in the investigated $\mathrm{ABE}$-ceramic artifacts. The contents of $\mathrm{P}_{2} \mathrm{O}_{5}$ range from 1.7 to $2.8 \mathrm{wt}$. \% (average of each tempers) and are represented basically by variscite-strengite and amorphous phosphates; apatite and rhabdophane are rare. Freestone \& Middleton (1987) reported contents of $\mathrm{P}_{2} \mathrm{O}_{5}$ in similar range within the clay matrix in some Far East ceramics. There the clay source and local soils contain less than $0.5 \mathrm{wt}$. \%. The local soils of Cahoeira-Porteira also show low $\mathrm{P}_{2} \mathrm{O}_{5}$ values, less than 0.036 wt. \% (Kern, 1988). In the modern ceramic artifacts, calcium phosphates are added to act as flux and to vitrify the final ceramic product. However, the ancient ceramics with high $\mathrm{P}_{2} \mathrm{O}_{5}$ content are not vitrified, so in this case, $\mathrm{P}_{2} \mathrm{O}_{5}$ was not

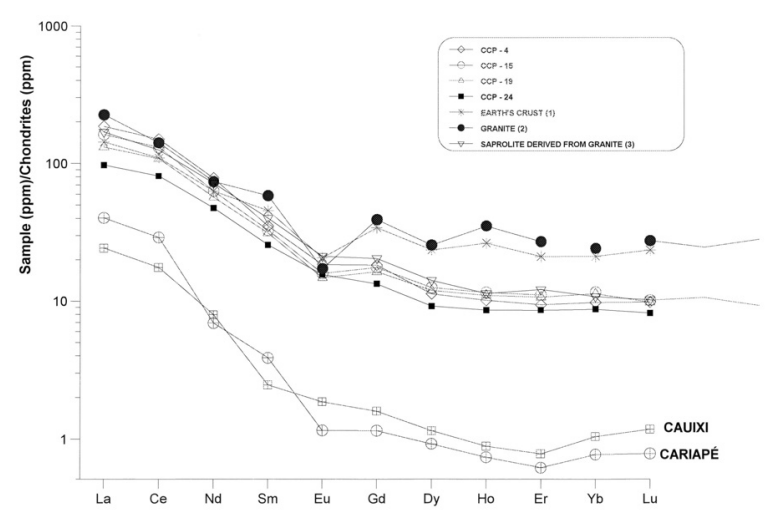

Figure 4 - REE concentrations normalized to chondrites and compared to Earth' crust abundance, granite, granitic saprolite, and cauixi and cariapé. (1)(2) KRAUSKOPF (1982); (3) DUDDY (1980). Chondrite REE were normalized after abundances of chondrites in WAKITA et al. (1971). used for this purpose (Freestone \& Middleton, 1987). Freestone \& Middleton conclude that $\mathrm{P}_{2} \mathrm{O}_{5}$ content is a result of environmental contamination. The mineral, a calcium phosphate but not apatite, is very fine-grained. In CachoeiraPorteira, the ceramic is not vitrified and the phosphorus contents in the ceramic fragments do not correlate with $\mathrm{CaO}$, under relatively low contents. Phosphorus forms (AlFe)-phosphates alone.

The ceramic fragments represent potteries of daily use, for cooking and stocking foods. The diets of the ancient Indians were similar to that of todays, basically of animal and vegetal origin. This diet includes meals make up of bones, liver, crumb, bowels, etc. as well as many different types of roots such as manioc, potatoes, yam, fruits of palm trees, different chestnuts (Brazil nut, and so on). Most of these foods may contain a high content of $\mathrm{P}_{2} \mathrm{O}_{5}$ as well as $\mathrm{Mn}, \mathrm{Ba}, \mathrm{Mg}, \mathrm{Zn},(\mathrm{Pb})$ (Scholz, 1980). The meals with bones and fishes, as well as nuts, were certainly the most important source of phosphorus. During long and repeatedly cooking and stocking of food there was transference of food components into ceramic vessels, that were even porous. During the cooking with much boiling water, which corresponds to a true high temperature water solution (hydrothermal solution), rich in the above mentioned elements released from the foods (Fig.6), like phosphorus, they go into the solution (broth or soup), and react with the clay-derived groundmass, disordered or amorphous. Disordered or amorphous clay or even crystalline clay minerals and iron oxyhydroxides react with phosphorus forming aluminous and iron phosphates such as variscitestrengite, crandallite group, wavellite, and so on (Kittrick et al., 1955; HSU, 1968; Kafkafi et al., 1967; Yariv et al., 1979 and Costa, 1982). In the archaeological ceramic fragments of Cachoeira-Porteira on average $94 \%$ of the phosphorus is absorbed (Table 3 ) in the mineral structure, confirming the presence of the phosphate phases. The kinetic of the phosphates formation increases under hydrothermal condition, and the cooking of food may be assigned as hydrothermal environment. The reactions for phosphate formation can be written as follows.

\section{Source of clays and rocks}

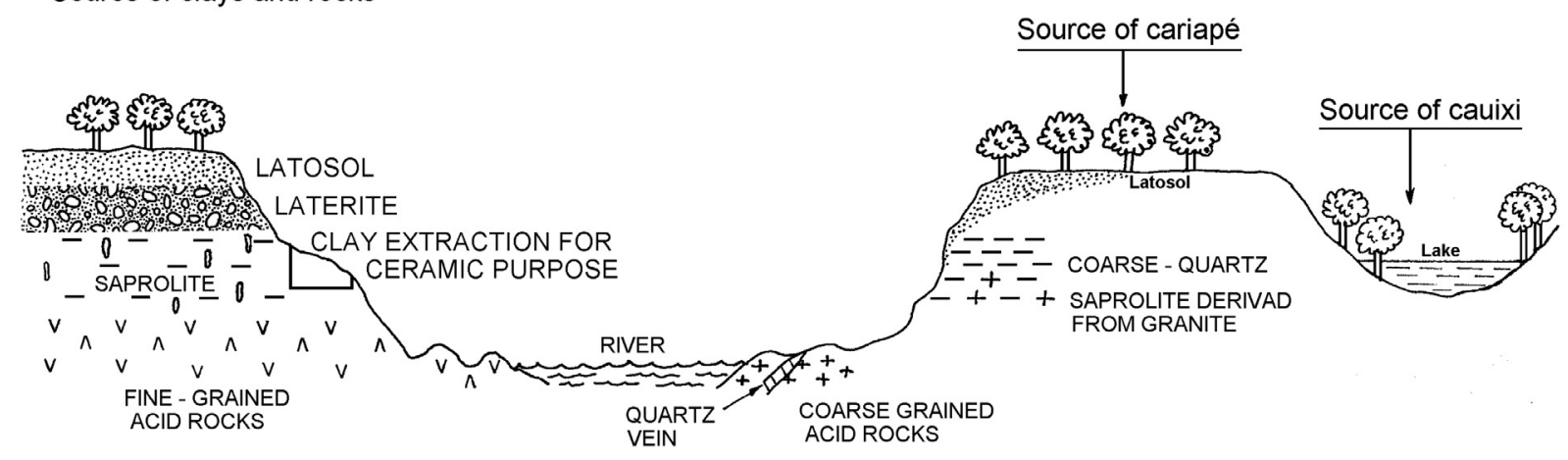

Figure 5 - Simplified geological cross-section showing the different sources of raw materials of archaeological potteries from CachoeiraPorteira. After COSTA et al., (2002). 


\section{ACTA AMAZONICA}

Table 3 - Disposable and total phosphorus in ABE-ceramics.

\begin{tabular}{lccc}
\hline \multicolumn{1}{c}{ SAMPLES } & DISPOSABLE PHOSPHORUS $(\mathrm{pPm})$ & $\begin{array}{c}\text { TOTAL } \\
\text { PHOSPHORUS(ppm) }\end{array}$ & $\begin{array}{c}\text { \% OF DISPOSABLE PHOSPHORUS } \\
\text { TO TOTAL PHOSPHORUS }\end{array}$ \\
\hline CCP-25 & 398 & 10,776 & 3.7 \\
CCP-26 & 580 & 17,241 & 3.4 \\
CCP-27 & 2100 & 18,996 & 11.1 \\
CCP-28 & 842 & 7,698 & 10.9 \\
CCP-29 & 351 & 15,733 & 2.2 \\
CCP-30 & 323 & 10,490 & 2.2 \\
CCP-31 & 189 & 14,655 & 1.3 \\
CCP-32 & 814 & 9,602 & 8.5 \\
CCP-33 & 291 & 7,602 & 3.8 \\
CCP-34 & 255 & 9,267 & 2.7 \\
CCP-35 & 1753 & 10,146 & 17.3 \\
CCP-36 & 765 & 5,819 & 13.1 \\
CCP-37 & 400 & 13,793 & 2.9 \\
CCP-38 & 281 & 9,063 & 3.1 \\
CCP-39 & 374 & 6,897 & 5.4 \\
CCP-40 & 514 & 11,638 & 4.4 \\
AVERAGE & 639 & 11,212 & 6.0 \\
\hline \hline
\end{tabular}

$\mathrm{Al}_{2} \mathrm{Si}_{2} \mathrm{O}_{5}(\mathrm{OH})_{4(\mathrm{~s})}+2 \mathrm{H}_{3} \mathrm{PO}_{4(\mathrm{aq})}+3 \mathrm{H}_{2} \mathrm{O} \Leftrightarrow 2 \mathrm{AlPO}_{4} \cdot 2 \mathrm{H}_{2} \mathrm{O}$ $+2 \mathrm{Si}^{2}(\mathrm{OH})_{4(\mathrm{aq})}$ or $\mathrm{SiO}_{2} \cdot \mathrm{H}_{2} \mathrm{O}_{(\mathrm{s})(1)}$ Kaolinite (clay) in boiling water variscite opal (ceramic body) water (broth or soup) (end-use of ceramics) $\mathrm{Fe}_{2} \mathrm{O}_{3}+2 \mathrm{H}_{3} \mathrm{PO}_{4(\mathrm{aq})}+\mathrm{H}_{2} \mathrm{O}$ $\Leftrightarrow 2 \mathrm{FePO}_{4} .2 \mathrm{H}_{2} \mathrm{O}_{(\mathrm{s})(2)}$ hematite strengite.

$\mathrm{H}_{3} \mathrm{PO}_{4}$ comes possibly from the desagregation and decomposition of organic material mainly bones and fishes during cooking, besides vegetal diet. The anomalous concentrations of $\mathrm{Ba}, \mathrm{Zn}$ and $\mathrm{Pb}$ (also $\mathrm{Zr}$, Sc and Mo ) in whole ceramics and of Ba and Mn in some places of clay-derived matrix might have come from animal and vegetal foods and precipitated as $(\mathrm{Ba}, \mathrm{Mn})$ oxyhydroxides, similarly to phosphates. This makes possible the potteries contamination by foods during cooking (Fig.6). This process might be responsible for promoting the formation of phosphates, manganese and barium oxides as mineral equivalents. The short time of the reactions (no older than the culture itself, 900 to 400 years BP) and low temperature (cooking temperature) can explain the low crystallinity and the very fine-grained nature of these neoformed minerals. It is possible that this kind of reactions (and contamination) may continue after the discarding of the ceramics (wastes) and during their incorporation into anthropic soil profile developed at the time of the settlement and after the abandonment of it (Fig.6), the formation of the black earth (ABE). The formation of phosphates, and locally of $\mathrm{Ba}, \mathrm{Mn}$ and REE minerals equivalents suggest that the pre-historic settlements at Cachoeira-Porteira were occupied by gathering and hunting people who stayed for a long time in the site, and possibly came back to the site several times..

\section{The Geochemical Evolution of $A B E-C e r a m i c s$}

900 to 400 years BP the pre-historic peoples lived in small groups along the margins of Trombetas/Nhamundá rivers and their lakes. For their daily necessities of transport, water keeping and food cooking, they made many ceramic artifacts (potteries). The majority of the artifacts were slightly painted and burned. The raw materials for making the potteries came certainly from neighboring areas close to sites and include clay material from a saprolite or mottled zone derived from rhyolite/ granite or from shales. Other materials are cauixi, cariapé and crushed rocks. All these materials are abundant in the area. This is the motive we assumed that the prehistoric peoples collected the raw materials around the area, close to the sites. The ceramic matrix is composed of $\mathrm{Si}, \mathrm{Al}, \mathrm{Fe}, \mathrm{Ti}$ and $\mathrm{Mg}$ (Fig. 6), which shows its still clayey composition. To improve the plasticity properties of this 


\section{ACTA AMAZONICA}

THE CERAMIC ARTIFACTS IN ARCHAEOLOGICAL BLACK EARTH (TERRA PRETA) FROM LOWER AMAZON REGION, BRAZIL: CHEMISTRY AND GEOCHEMICAL EVOLUTION matrix the Indians intentionally added either cauxi, cariapé, quartz sand or crushed rocks and feldspars, that promoted a $\mathrm{SiO}_{2}$-enrichment, sn important chemical aspect of the tempers. The addition of feldspars, which obviously contributes with $\mathrm{K}$, $\mathrm{Na}$ and $\mathrm{Ca}$ into raw material improves the firing temperature.

The firing of the potteries occur in open atmosphere (Fig.6), possibly in the same primitive way as the actual Indians and caboclos still do. The firing temperature didn't exceed $600{ }^{\circ} \mathrm{C}$, as demonstrated by partial dehydroxylation of clay material and the formation of maghemite. This phase formed the ceramic minerals: dehydroxylation of clay giving rise to burned clay, maghemite and recrystallization of anatase. Maghemite promotes the slightly brown to red color of the potteries.

After much firing potteries were used for daily purposes as cooking and conserving foods. At this phase they get in contact with meals, fishes, roots and so on, in boiling water, become contaminated and form minerals like aluminum phosphates and Ba-Mn oxyhydroxides mineral equivalents (post-ceramic minerals), which may contain the elements $\mathrm{Mg}, \mathrm{Ca}, \mathrm{Ba}, \mathrm{Zn}, \mathrm{Pb}, \mathrm{Y}$, and so on.

Finally the potteries after several uses become old, break down and are discarded together with many other organic (vegetal and animal) material waste. Gradually the biological and chemical-weathering agents which are very active under the humid and tropical climate in the region for the last 10.000 years, attack them. After the people leave the site the rain forest envelopes the area and the weathering becomes more active and develops the soil profiles incorporating the great organic matter coming from pre-historic people waste. Chemical elements such $\mathrm{P}, \mathrm{Mg}, \mathrm{Ca}, \mathrm{Mn}, \mathrm{Ba}, \mathrm{Zn}, \mathrm{Pb}$, etc. are fixed partly and concentrated in the organic humus of $\mathrm{ABE}$ soils and possibly is partly absorved in the ceramic fragments, contributing to formation of phosphates and $\mathrm{Mn}$ oxyhydroxides in less extension. During this phase the clayderived materials and hematite/maghemite rehydrated and form kaolinite and goethite, respectively (post-ceramic minerals or pedogenic minerals)(Fig.6). The concentration of ceramic fragments in the A horizons shows that the ABE development is restrict to the top of pre-existing latosols. The high content of organic matter of the A horizons explains its gray color, caused the deferrugination the outer skin of the ceramic fragments, which become yellowish gray.

\section{ACKNOWLEDGMENTS}

We would like to thank the full assistance of the Companbia Brasileira de Metalurgia e Mineração - CBMM in conducting the SEM/EDS analyses in their laboratory, especially the contribution of Dr. Bruno Riffel and Dr. Abrahão Issa Filho. The financial support of Brazilian National Program for Development of the Sciences and Technology (PADCT/FINEP) and Brazilian National Council for Sciences and Technology (CNPq). We are grateful to Anselmo José Monteiro dos Santos, who made the first drawings of this paper and to Elias Leão Moraes for his contribution during the elaboration of the computer drawings. The authors would like to thank the two anonymous reviewers for their very important suggestions for manuscript corrections.

\section{LITERATURE CITED}

Baleé, W. 1986 The culture of Amazonian forest. In: Posey, D.A. Baleé, W. (eds.). Resource management in Amazon: indigenous and flak strategies. Advance in Economic Botany, 7, New York, NY Botanical Garden.

Baleé, W. 1989 Cultura na Vegetação da Amazônia Brasileira. Bol. Mus. Para. Emílio Goeldi, Coleção Eduardo Galvão. p. 95 - 109.

Costa, M.L. 1982 Petrologisch-geochemische Untersuchungen zur Genese der Bauxite und Phosphat-Laterite der Region Gurupi (Ost-Amazonien). PhD Thesis. Erlangen-Nuernberg University. Germany.,189 p. 


\section{ACTA AMAZONICA}

Costa, M.L. 1991 Aspectos geológicos dos lateritos da Amazônia. Revista Brasileira de Geociências., 21 (2):146 160.

Costa, M.L. 1997 Lateritisation as a major process of ore deposit formation in the Amazon region. Exploration Mining Geology, 6(1): $79-104$

Costa, M.L., Kern, D.C., Pinto, A.H.E., Souza, J.R.T., 2004, The ceramic artifacts in archaeological black earth from Lower Amazon Region, Brazil: Mineralogy. Acta Amazonica 34 (2): $165-178$

-Costa, M.L.; Kern, D.C.; Souza, J.R.T.; Pinto, A.H.E. 1991 A mineralogia e a geoquímica na cerâmica arqueológica de Oriximiná, PA. In: Proceedings of the 3rd Brazilian Geochemical Congress, São Paulo, SBGq, 1: 1-3

Costa, M.L.; Kern, D.C. 1999 Geochemical signatures of tropical soils with archaeological black earth in the Amazon. Journal of Geochemical Exploration, 66(1/2), 369-385.

Costa, M.L.; Moraes, E.L. 1998 Mineralogy, geochemistry and genesis of kaolins from the Amazon region. Mineralium Deposita, 33 (3):283-297.

Dixon, J.B.,1989, Kaolin and serpentine group minerals. In: J.B. Dixon; S.B. Weed - ed. Minerals in soil environments. Soil Sciences Society of America, $2^{\text {nd }}$. Ed., Madison, p. 467-525.

Duddy, I.R., 1980 Distribution and fractionation of rare-earth elements and other elements in a weathering profile. Chemical Geology, 30:363-444.

Eden, M.J.; Bray, W.; Herrera,L.; Mcevan, C. 1984 Terra Preta Soils and their archaeological context in the Caquetá Basin of Southeast Colombia. American Antiquity, 49(1)125-140.

Falesi, I. 1974 Soils of Brazilian Amazon. In: Ch.Wagley. ed. Man in the Amazon. Gainesville, p. 201-29.

Freestone, F.C.; Middleton, A.P. 1987 Mineralogical applications of the analytical SEM in archaeology. Mineralogical Magazine, 51:21-31.

Hilbert, P.P. 1955 A cerâmica arqueológica da região de Oriximiná. Belém, Instituto de Antropologia e Etnologia do Pará. p.76.

Hsu, P. 1968 Interaction between aluminum and phosphate in aqueous solution. Adv. Chem., 73: 115-127.

Kafkafi, U., Posner, A.M.; Quirk, J.P. 1967 Desorption of phosphate from kaolinite. Soil Sciences Society of America, 31:348-353.

Kern, D.C. 1988 Caracterização pedológica de solos com terra arqueológica na região de Oriximiná-PA. Porto Alegre. MSc Thesis. Soils Department, Universidade Federal do Rio Grande do Sul. 231p.

Kern, D.C. 1996 Geoquímica e pedogeoquímica em Sítios Arqueológicos com Terra Preta na Floresta Nacional de Caxiuanã (Portel-PA). Doctor Thesis, Centro de Geociências. Universidade Federal do Pará. 124 p.

Kern D.C.; Kämpfn, N. 1989 O Efeito de Antigos Assentamentos Indígenas na Formação de Solos com Terra Preta Arqueológica na Região de Oriximiná-Pa. Revista Braileira de Ciências do Solo, 13:219-25.

Kern, D.C.; Kämpf, N., 1990 Características Físicas e Morfológicas dos Solos com TPA e sua importância para os estudos Arqueológicos. Santa Cruz do Sul - RS. Newsletter CEPA, 17(20): 277-85.
Kern, D.; Costa, M.L. 1997 Os Solos Antrópicos. In: P. L.B. Lisboa (Org.) - Caxiuanã. MCT/CNPq, Museu Paraense Emílio GoeldiMPEG, Belém-PA, p. 105-119.

Kittrick, J.A.; Jackson, M.L. 1955 Rate of phosphate react ion with soil minerals and electron microscope. Observations on the reaction mechanism. Soil Sciences Society of America, 19: 292-295.

Krauskopf, K.B. 1982 Introduction to geochemistry. McGraw-Hill, Auckland, p. 617.

Letsch, J.; Noll, W. 1983 Mineralogie und Technik der frühen Keramiken Thessaliens. Neues Jabrbuch Mineralogie Abhandlung, 147(2):109-146.

Meggers, B.J.; Evans, C. 1970 Como interpretar a linguagem da cerâmica. In: Manual para arqueólogos. Smithsonian Institution. Washington, p. 111

Melatti, J.C. 1972 Indios do Brasil. Etnologia Brasileira. 2a ed. Brasília. p.236.

Momsen, H. 1986 Archaeometrie: Neuere naturwissenschaftliche Methoden und Erfolge in der Archaeologie. B.G. Teubner Stuttgart, p. 304.

Nimuendaju, C. (1948) Os Tapajós. Museu Paraense Emílio Goeldi Newsletter, 10:93-106.

Noll, W., 1978 Mineralogie und Technik der bemalten Keramiken Altägyptens. Neues Jabrbuch, Mineralogie-Abbandlung, 133(3): 227-290.

Ranzani,G.; Kinjo,T.; Freire,O. 1962 Ocorrência de "Plaggen Epipedon" no Brasil. Boletim Técnico-Científico da Escola Superior de Agricultura "Luiz de Queiroz" 5:1-11.

Redmount,C.A . 1996 Major and trace element analysis of modern Egyptian pottery.Journal of Archaeological Science, 23: 741-762.

Roosevelt, A.C.; Costa. M.L; Lopes Machado, C.; Michab, M.; Mercier, N.; Valladas, H.; Feathers, J.; Barnett, W.; Imazio da Silveira, M.; Herderson, A.; Silva, J.; Chernoff, B.; Reese, D.S.; Holman, J.A.; Toth, N.; Schick, K. 1996 Paleo-Indian Cave Dwellers in the Amazon the Peopling of the Americas. Science. 272: 373-384.

Scholz, H. 1980 Mineralstoffe und Spurenelemente - nötig fuer unserer Gesundheit. Paracelsus Verlag, p. 192.

Simões, M.F. 1982 A Pré-História da Bacia Amazônica: Uma tentativa de reconstituição. In: Cultura Indígena, textos e catálogo. Semana do Índio, Museu Goeldi, Belém, p:5-21.

Sjoberg, A. 1976 Phosphate Analysis of Anthropic Soil.Journal of Field Archaeology, 3:448-454.

Smith, H.H. 1879 The amazons and the coast. Charles Scribner's sons, New York, 644p.

Smith, N.J.H. 1980 Anthrosols and Human Carrying Capacity in Amazonia, In: Annals of the Association of American Geographers, 70(4):553-66.

Sombroek, W. 1966 Amazon soils: A Reconnaissance of the Soils of the Brazilian Amazon Region. Wageningen, Center for Agricultural Publications and Documentation. 292 p.

Strazicich, N.M. 1998 Clay sources, pottery production, and regional economy in Chalchihnites, Mexico, A . D. 200-900. Latin American Antiquity, 9(3): 259-274. 
Yariv, S.,; Cross, H. 1979 Geochemistry of colloid systems. SpringerVerlag, Berlin, $450 \mathrm{p}$.

Zaun, P. E. 1982 Über Bodenlagerung auf antike Keramik. Mineralneuund -rueckbildungen als moegliche Grundlagen fuer neue Datierungshilfen. Ein Beitrag zur archaeometrischen Forschung. Neues Jabrbuch fuer Mineralogie, Monatsheft, 3: 106-118.

Wada, K. 1989 Allophane and imogolite. In: J.B. Dixon; S.B. Weed - ed. Minerals in soil environments. Soil Sciences Society of America, Madison, $2^{\text {nd }}$. Ed., p. 1051-1087.
Wakita, H., Rey, P. Schimitt, R.A.1971.Abundances of the 14 rare earth elements and 12 other trace elements in Apollo 12 samples: five igneous and one breccia rocks and four soils. Proc. Second Lunar Sci. Conf., 2, The M.I.T. Press, pp.1319-29. 